Article

\title{
Effects of Strategic Tillage on Soil Physicochemical Properties and Grain Yield in the North China Plain
}

\author{
Qiuyue Liu, Zhengrong Kan, Cong He and Hailin Zhang *(D) \\ Key Laboratory of Farming System of Ministry of Agriculture and Rural Affairs of China, College of Agronomy \\ and Biotechnology, China Agricultural University, Beijing 100193, China; S20193010020@cau.edu.cn (Q.L.); \\ kzr@cau.edu.cn (Z.K.); S20193010021@cau.edu.cn (C.H.) \\ * Correspondence: hailin@cau.edu.cn; Tel./Fax: +86-10-6273-3376
}

Received: 12 July 2020; Accepted: 6 August 2020; Published: 8 August 2020

\begin{abstract}
No-till (NT) practice has been widely adopted to improve soil quality, but soil compaction and soil organic carbon (SOC) stratification under long-term NT limit crop production. Strategic tillage (ST), based on single tillage, is proposed as an attractive management practice to sustain the benefits of continuous NT and mitigate its adverse effects. Four tillage systems, including continuous rotary tillage (RT), NT, rotary tillage + subsoiling (RS), and no-till + subsoiling (NS), were implemented to investigate the effects of strategic tillage (i.e., RS and NS) on soil physical properties (compaction and aggregates), SOC, and crop yield in the North China Plain (NCP). The results showed that ST as expected decreased soil bulk density, penetration resistance, and SOC stratification compared with RT and NT at $0-20 \mathrm{~cm}$ soil depth $(p<0.05)$. At $0-10 \mathrm{~cm}$ soil depth, more macroaggregates $(>0.25 \mathrm{~mm})$ were observed in NT and NS, contributing to higher mean weight and geometric mean diameters, this compared with RT and RS. Additionally, macroaggregate associated SOC was higher, thus resulting in higher SOC storage in NT (31.4-33.4 Mg ha $\left.{ }^{-1}\right)$ and NS (33.3-35.4 $\left.\mathrm{Mg} \mathrm{ha}^{-1}\right)$ at $0-30 \mathrm{~cm}$ depth $(p<0.05)$. Low soil compaction and high SOC in NS were beneficial for the grain yield of wheat and maize, significantly higher by $8.7-32.5 \%$ and $14.0-29.8 \%$ compared with the other treatments, respectively $(p<0.05)$. Based on our findings, NS seems to be a promising alternative tillage system to improve soil physicochemical properties and crop production in the NCP. More studies are therefore needed to better understand the benefit of NS.
\end{abstract}

Keywords: strategic tillage; no-till; soil organic carbon; aggregate; grain yield

\section{Introduction}

Soil carbon $(\mathrm{C})$ pool is the third principal global C stock, containing 1462-1548 Pg in the upper $1 \mathrm{~m}$ soil depth as soil organic carbon (SOC) [1]. It is currently believed that strengthening SOC sequestration in soil can be an effective measure to mitigate greenhouse gas emissions [2]. No-till (NT) has been broadly accepted as a beneficial method to sequester SOC, enhance aggregate stability, improve soil quality, save fuel and energy, and avoid adverse effects induced by continuous intensive tillage [3-5]. It has been estimated that $9-15 \%$ of global arable land is currently managed using NT practices, possibly rising to $38-81 \%$ in the future [6]. However, continuous NT practice has some constraints, such as low SOC accumulation in deep soil depths [7,8], mechanical compaction [9-11], and yield reduction [12,13], all of which can limit widespread adoption of this management system.

Based on an investigation in China using meta-analysis, Zhao et al. [13] reported that crop yield under NT decreased by $2.1 \%$ compared with conventional tillage, similar results were recorded globally [12]. Due to an increase in soil bulk density (BD) and penetration resistance (PR), long-term NT resulted in higher soil surface compaction, thereby affecting crop yield by limiting root system expansion, oxygen, water, and nutrient uptake [1]. Strategic tillage (ST), based on continuous 
single tillage, has been regarded as a potential alternative due to its capacity to assist in removing the compacted soil layer induced by continuous NT [14]. However, the effects of changes in soil compaction on grain yield were rarely reported. For example, Crawford et al. [15] recorded no significant differences of wheat, chickpea, and barley yields between ST and continuous NT in the northern grain region in Australia. In contrast, Wang et al. [16] reported that compared with continuous NT, ST significantly reduced the risk of rice yield reduction in Southern China. The effects of ST on soil quality, crop productivity, and environmental health were examined by Dang et al. [17], reporting contradictory findings among different soil types. Previous studies have reported that NT can improve the macroaggregate formation and enhance aggregate stability due to minimum disturbance [18]. However, effects of ST on soil disturbance and aggregate stability are still unknown. For example, for silty loam and silty clay loam soils, Wortmann et al. [19] reported that ST had no significant effect on aggregate stability, while for coarse and fine loamy soils, negative effects were observed [20]. In addition, results from investigations using a meta-analysis in China have shown that NT had higher SOC concentration and stock at the surface layer and lower SOC at the deep layer compared with plow tillage [7], and thus a higher stratification rate of SOC was observed under NT compared with the other tillage system [8,9]. The results by Wang et al. [16] in Southern China showed ST to reduce SOC concentration compared with NT at $0-5 \mathrm{~cm}$ soil depth, but information on stratification rates of SOC under ST is limited. Soil aggregate formation is also linked to soil SOC dynamics [21]. Macroaggregates can protect SOC from mineralization, thereby providing a positive relationship between SOC concentration and aggregate stability. Although ST decreased aggregate stability at surface layers compared with NT, higher values have been recorded at $10-30 \mathrm{~cm}$ depth [14]. Therefore, ST may have the potential to improve SOC levels at a deep depth and decrease the stratification ratio (SR) of SOC.

The North China Plain (NCP) is an important food production base, containing $18.3 \%$ of the national total farmland supplies and producing approximately $25 \%$ of the total grain yield (wheat and maize) in China [22]. As demand for food has increased, intensive agricultural management practices have been adopted, such as intensive tillage, irrigation, and fertilizer application, resulting in negative effects on soil quality. Due to these effects, conservation tillage, based on NT and straw retention, has been examined and adopted in the NCP. However, conservation tillage in the NCP has resulted in a higher potential to reduce grain yield compared with other regions in China [3], thereby limiting its practical use. It has therefore become important to rapidly develop a suitable method of sustainable agricultural production in the NCP. It is believed that ST practices may offer a potential solution to solve problems related to yield reduction, as well as sustaining benefits gained from conservation tillage. However, current understanding of soil aggregate stability, associated SOC, soil compaction, and grain yield under ST management practices in this region is limited. We hypothesize that ST can improve the SOC concentration at deeper soil depths, decreasing stratification rates, and soil compaction, thereby resulting in an improvement in the grain yield. The objectives of this study, therefore, were: (i) to assess aggregate stability and associated SOC to a depth of $50 \mathrm{~cm}$ under ST and continuous tillage; (ii) to evaluate the stratification rate of SOC under ST and continuous tillage; and (iii) to identify soil compaction and grain yield (wheat and maize) under conditions of ST and continuous tillage.

\section{Material and Methods}

\subsection{Site Description}

This study was initiated in October 2015 at the Wuqiao Experimental Station ( $37^{\circ} 36^{\prime} \mathrm{N}, 116^{\circ} 21^{\prime} \mathrm{E}$ ) of the China Agricultural University, located in Hebei Province in the NCP region. Over the last 30 years, this region has recorded an average annual temperature of $12.6{ }^{\circ} \mathrm{C}$ and mean annual precipitation of $531.1 \mathrm{~mm}$. Mean temperature and precipitation during the experiment are presented in Figure 1; about $60-70 \%$ of annual rainfall was recorded to occur between June and September. According to the 
USDA classification system, soil texture was the silt texture ( $71.20 \%$ silt, $18.62 \%$ sand, and $10.18 \%$ clay). Primary soil properties before the experiment was undertaken are shown in Table 1 . The cropping system used in this region was winter wheat-summer maize.

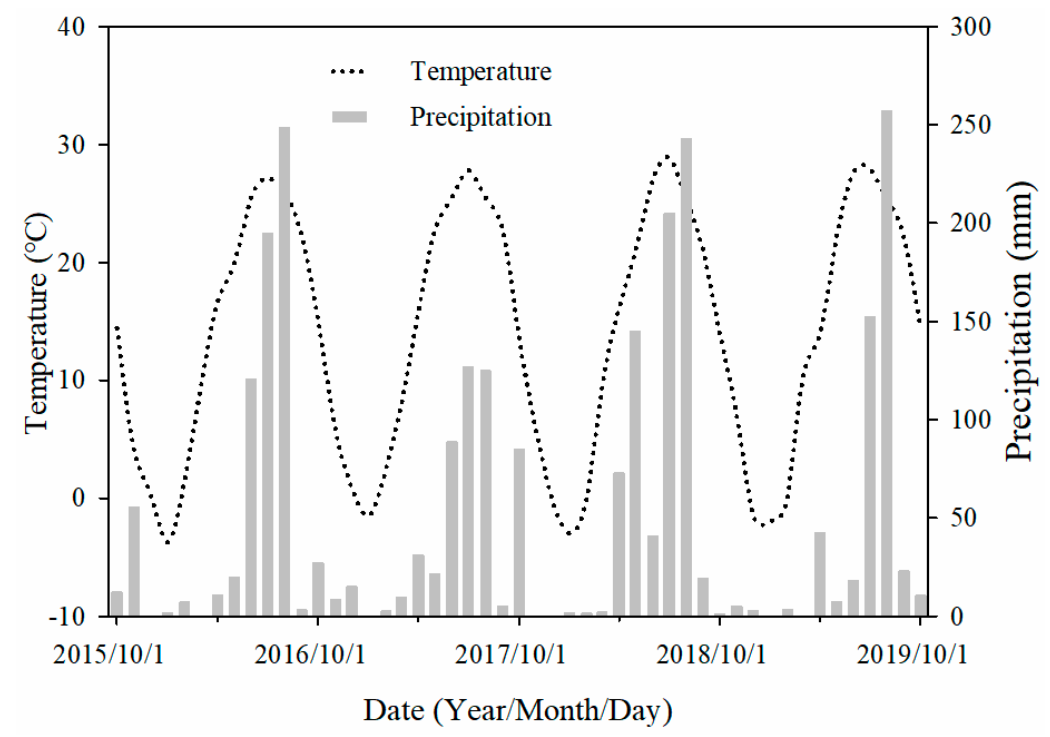

Figure 1. Mean temperature and total precipitation of the experimental duration at Wuqiao Station.

Table 1. Basic soil properties at 0-20 $\mathrm{cm}$ soil depth before the experiment (2015).

\begin{tabular}{cc}
\hline Soil Properties & Values \\
\hline Bulk density & $1.30 \mathrm{~g} \mathrm{~cm}^{-3}$ \\
Soil organic carbon & $8.25 \mathrm{~g} \mathrm{~kg}^{-1}$ \\
Total nitrogen & $0.75 \mathrm{~g} \mathrm{~kg}^{-1}$ \\
Available nitrogen & $35.12 \mathrm{mg} \mathrm{kg}^{-1}$ \\
Available potassium & $92.34 \mathrm{mg} \mathrm{kg}^{-1}$ \\
Available phosphorus & $40.35 \mathrm{mg} \mathrm{kg}^{-1}$ \\
\hline
\end{tabular}

\subsection{Experimental Design and Farm Management}

This study was undertaken using a randomized complete block design with four treatments and three replications ( 12 plots of $16 \mathrm{~m} \times 16 \mathrm{~m}$ ) each. The four treatments were RT (rotary tillage), RS (rotary tillage and subsoiling), NT (no-till), and NS (no-till and subsoiling; Table 2). During the first two years (2015 and 2016), only RT and NT treatments were undertaken. In 2017, NT and RT plots were divided into two categories, with half of these plots being tilled by subsoiling up to $0-30 \mathrm{~cm}$ depth, defined as strategic tillage.

Tillage operations were only adopted in the winter wheat season. For the RT system, a rotary tillage machine with a depth set to $10 \mathrm{~cm}$ was used before seeding. Wheat was seeded directly into the soil in the NT system using a no-till planter (Nonghaha Machinery Group in Hebei Province), and no other tillage measures were used in this system. The no-till planter operates by opening a small trench, automatically sowing and covering the soil, then finally pressing the soil. For strategic tillage (RS and NS), subsoiling was done to a depth of $30 \mathrm{~cm}$, followed by rotary tillage up to $10 \mathrm{~cm}$ twice to establish a smooth seedbed before wheat was sown. Maize residues concentrated on the surface were chopped into 5-10 cm pieces and left on the soil surface for NT; RT treatment incorporated this residue into the soil (up to $10 \mathrm{~cm}$ depth). Direct seeding was used for summer maize without tillage using the no-till method, consistent with local practices. As per local practices, the wheat residue was also left to cover the soil surface.

The seeding rates of wheat and maize were $300 \mathrm{~kg} \mathrm{ha}^{-1}$ and 67,500 plants ha ${ }^{-1}$, respectively. The rate and type of fertilizer applications of all plots were kept the same. Base fertilizer before 
experiment initiation was $243 \mathrm{~kg} \mathrm{~N} \mathrm{ha}^{-1}, 103.5 \mathrm{~kg} \mathrm{pha}^{-1}$ and $107 \mathrm{~kg} \mathrm{~K} \mathrm{ha}^{-1}$ for winter wheat. In addition, at the jointing stage, $75 \mathrm{~kg} \mathrm{~N} \mathrm{ha}^{-1}$ was applied. A base fertilizer of compound fertilizer (525 $\mathrm{kg} \mathrm{ha}^{-1} ; \mathrm{N}: \mathrm{P}_{2} \mathrm{O}_{5}: \mathrm{K}_{2} \mathrm{O}=22: 8: 10$ ) was applied in the summer maize season. Irrigation frequency and duration were also kept the same for all plots. During the winter wheat season, irrigation occurred two or three times (60-70 mm each time), with the frequency being adapted due to weather conditions.

Table 2. Tillage operations utilized during the study period.

\begin{tabular}{ccccc}
\hline Year & RT & RS & NT & NS \\
\hline 2015 & rotary tillage & rotary tillage & no-till & no-till \\
2016 & rotary tillage & rotary tillage & no-till & no-till \\
2017 & rotary tillage & subsoiling & no-till & subsoiling \\
2018 & rotary tillage & rotary tillage & no-till & no-till \\
2019 & rotary tillage & rotary tillage & no-till & no-till \\
\hline
\end{tabular}

RT, continuous rotary tillage; RS, rotary tillage + subsoiling; NT, long-term no-till; NS, no-till + subsoiling.

\subsection{Soil Sampling and Analyses}

After maize was harvested in October 2018 and 2019, bulk soil samples were collected from three locations on each plot using a soil auger. Soil samples collected from the same soil layers $(0-10,10-20$, 20-30, and 30-50 cm) at each plot were mixed. Soil samples for aggregate distribution and associated SOC were obtained in each plot using cylinders $(15 \mathrm{~cm}$ diameter) for the same layer interval as listed above after maize was harvested in October 2019. Aggregate samples were sealed using aluminum lunch boxes and returned to the laboratory for analysis.

\subsection{Bulk Density and Penetration Resistance}

During maize maturity, three undisturbed soil samples were collected for bulk density (BD) analysis in each plot from $0-10,10-20,20-30$, and 30-50 cm depths using a $5.0 \mathrm{~cm}$ high and $5.0 \mathrm{~cm}$ internal diameter cylinder, and then dried at $105^{\circ} \mathrm{C}$ for 24 hours for measuring BD. Soil penetration resistance (PR) for a soil depth of $0-50 \mathrm{~cm}$ was determined using a hand-held digital cone head (SC900, Semtech Corporation, Camarillo, CA, USA) soil hardness tester.

\subsection{Aggregates Distribution and Stability}

Air-dried soil samples were peeled into soil blocks with a diameter of about $10 \mathrm{~mm}$; visible organic residues were removed using tweezers. Each soil sample was divided into four aggregate grades using dry screening, as per the method of Kan et al. [23]. In summary, $300 \mathrm{~g}$ of the sample was shaken for three minutes using an electric vibrating screen with apertures $2,0.25$, and $0.053 \mathrm{~mm}$ to obtain four aggregate sizes (AS): AS $>2 \mathrm{~mm}$, AS $=0.25-2 \mathrm{~mm}$, AS $=0.053-0.25 \mathrm{~mm}$, and AS $<0.053 \mathrm{~mm}$.

Mean weight diameter (MWD) and geometric mean diameter (GMD) were calculated as [24,25]:

$$
\begin{gathered}
M W D=\frac{\sum_{i=1}^{n}\left(W_{i} \times X_{i}\right)}{\sum_{i=1}^{n} W_{i}} \\
G M D=\exp \left[\frac{\sum_{i=1}^{n} W_{i} \times \ln \left(X_{i}\right)}{\sum_{i=1}^{n} W_{i}}\right]
\end{gathered}
$$

where, $W_{i}$ is the weight percentage of each particular size; $X_{i}$ is the mean diameter of each particular size.

\subsection{Aggregate Associated Organic Carbon, SOC and SOC Storage}

SOC and aggregate associated SOC were determined using $\mathrm{K}_{2} \mathrm{Cr}_{2} \mathrm{O}_{7}$ oxidation and titration by the $\mathrm{Fe}_{2} \mathrm{SO}_{4}$ solution on air-dried bulk soil samples and aggregates passed through a $0.25 \mathrm{~mm}$ sieve [26]. The SR was determined using the method of Franzluebbers [27]. In summary, SOC concentration 
at $0-10 \mathrm{~cm}$ soil depth divided by SOC concentrations at $10-20 \mathrm{~cm}, 20-30 \mathrm{~cm}$, and $30-50 \mathrm{~cm}$ depths, respectively, as the SR of this depth. SOC storage was calculated using the equal mass method:

$$
\text { SOC storage }=\left[\sum_{i=1}^{n} M_{\text {soil }, i} \times C_{i}+\left(\sum_{i=1}^{n} M_{o, i}-\sum_{i=1}^{n} M_{\text {soil }, i}\right) \times C_{i+1}\right] \times 0.001
$$

where, $M_{\text {soil, }}$ is the soil mass $\left(\mathrm{Mg} \mathrm{ha}^{-1}\right)$ in layer " $\mathrm{i}^{\prime \prime}$ ( $\mathrm{i}=1,2,3$ and 4, representing 0-10, 10-20, 20-30, and 30-50 cm depths, respectively); $\sum_{i=1}^{n} M_{\text {soil, },}$ is the sum of soil mass $\left(\mathrm{Mg} \mathrm{ha}^{-1}\right)$ from layer ${ }^{\prime \prime} 1^{\prime \prime}$ to ${ }^{\prime \prime} \mathrm{n}^{\prime \prime}$; $\mathrm{C}_{\mathrm{i}}$ is the SOC concentration $\left(\mathrm{g} \mathrm{kg}^{-1}\right)$ in layer " $\mathrm{i}^{\prime \prime}$; and $\sum_{i=1}^{n} M_{0, i}$ is the greatest sum soil mass $\left(\mathrm{Mg} \mathrm{ha}^{-1}\right)$ from layer " 1 " to $" \mathrm{n}^{\prime \prime}$ among treatments.

\subsection{Grain Yield}

At the maturity stage of winter wheat, above-ground biomass with an area of $2 \mathrm{~m}^{2}$ from each plot was artificially harvested. The standard moisture content of $13 \%$ of grain yield was determined after 1-2 weeks of sun exposure. At the summer maize maturity stage, $1.2 \mathrm{~m}$ (two rows) $\times 5 \mathrm{~m}$ areas were selected in each plot to determine grain yield after natural drying.

\subsection{Statistical Analysis}

Normal distribution and homogeneity of variance were initially tested on the data set. Statistical analysis was conducted using SPSS software 20.0 (SPSS Inc., Chicago, IL, USA). One-way analysis of variance (ANOVA) was conducted to test the effects of treatments with the least significant difference (LSD) at the $p<0.05$ level for means separation.

\section{Results}

\subsection{Bulk Density and Penetration Resistance}

The bulk density (BD) at $0-10 \mathrm{~cm}$ soil depth was lowest under RS $\left(1.30 \pm 0.05 \mathrm{~g} \mathrm{~cm}^{-3}\right)$ and NS $\left(1.30 \pm 0.04 \mathrm{~g} \mathrm{~cm}^{-3}\right)$, followed by RT $\left(1.42 \pm 0.05 \mathrm{~g} \mathrm{~cm}^{-3}\right)$ and NT $\left(1.53 \pm 0.01 \mathrm{~g} \mathrm{~cm}^{-3} ; p<0.05\right.$; Figure 2a). Similar trends were recorded for BD at 10-20 cm depth, with NT recording the highest values. The differences of BD under different treatments at $20-30$ and 30-50 cm depths were not significant. Higher penetration resistance (PR) was observed in NT, by $18.4 \%, 29.6 \%$, and $29.8 \%$ at $0-10 \mathrm{~cm}$ depth and by $5.3 \%, 12.2 \%$, and $14.0 \%$ at $10-20 \mathrm{~cm}$ depth than RT, RS, and NS, respectively $(p<0.05)$ (Figure 2b). No significant difference was observed among treatments at $20-50 \mathrm{~cm}$ depth.
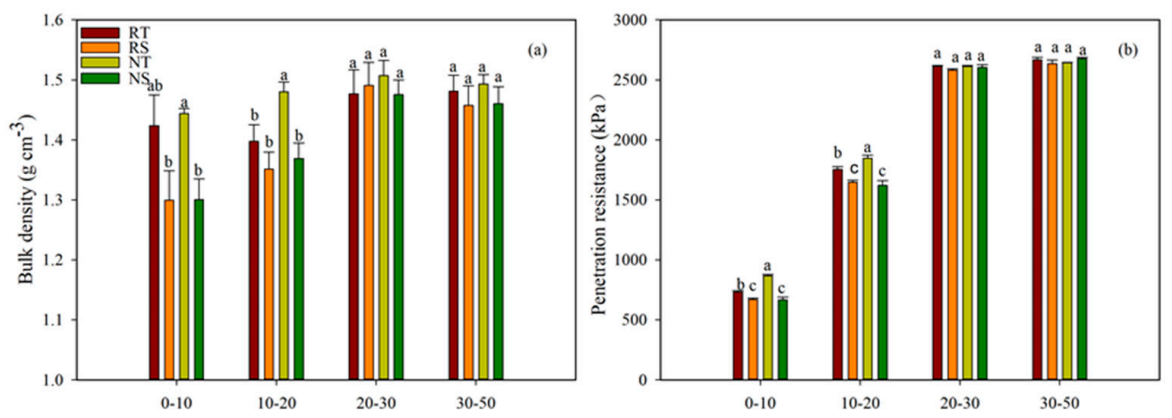

Figure 2. Effects of strategic tillage on bulk density (a) and penetration resistance (b). RT, continuous rotary tillage; RS, rotary tillage + subsoiling; NT, long-term no-till; and NS; no-till + subsoiling. Lowercase letters mean a significant difference at the 0.05 level among treatments. Error bars represent the standard error of the mean $(n=3)$. 


\subsection{Aggregates Size Distribution}

At $0-10 \mathrm{~cm}$ depth, the percentages of $\mathrm{AS}_{>2 \mathrm{~mm}}$ under RT $(52.6 \%)$ and RS $(53.3 \%)$ were significantly lower than that of NT (58.9\%) and NS (57.2\%; Figure 3). A similar trend was observed for AS $_{0.25-2}$, following the order of NS $>$ NT $>$ RT $>$ RS. At the 10-20 cm depth, an opposite trend was observed for $\mathrm{AS}_{>2 \mathrm{~mm}}$, with RT and RS higher than NT and NS; NT and NS, however, were higher than RT and RS for $\mathrm{AS}_{0.25-2 \mathrm{~mm}}$. The percentages of $\mathrm{AS}_{>2 \mathrm{~mm}}$ and $\mathrm{AS}_{0.25-2 \mathrm{~mm}}$ did not significantly differ among the four treatments at $20-30 \mathrm{~cm}$ depth. At 30-50 cm depth, the percentage of $\mathrm{AS}_{>2 \mathrm{~mm}}$ under NT was the lowest.

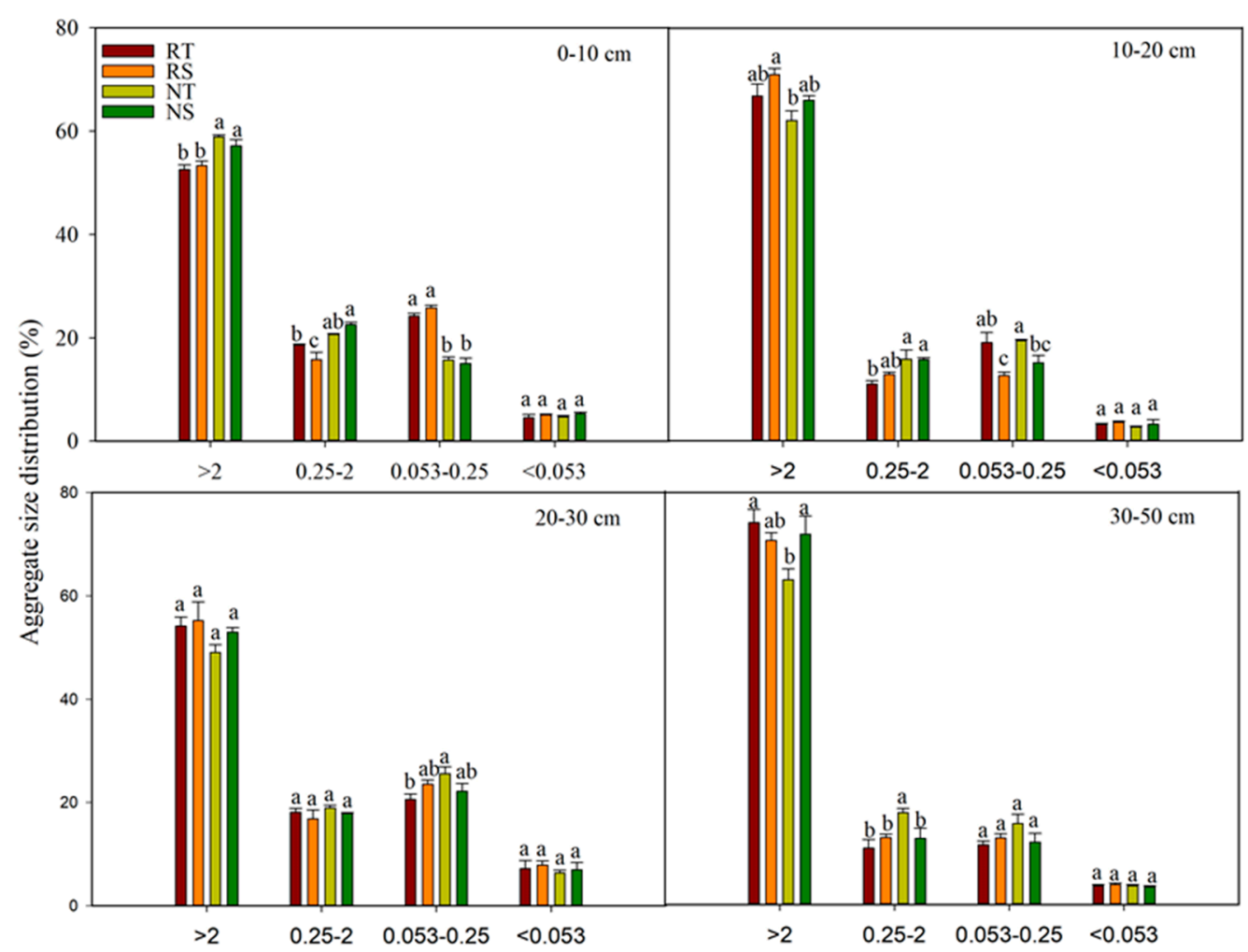

Figure 3. Effects of strategic tillage on aggregate size distribution. RT, continuous rotary tillage; RS, rotary tillage + subsoiling; NT, long-term no-till; and NS, no-till + subsoiling. Lowercase letters mean a significant difference at the 0.05 level among treatments. Error bars represent the standard error of the mean $(n=3)$.

\subsection{Mean Weight Diameter and Geometric Mean Diameter}

The highest MWD and GMD were observed in NT, being 1.9\%, $11.1 \%$, and $11.1 \%$ higher than NS, RS, and RT in MWD, and 3.8\%, 35.0\%, and 29.7\% higher in GMD, respectively at 0-10 cm depth (Table 3). No significant difference was observed in MWD and GMD between NT and NS. At 10-20 cm depth, higher MWD and GMD were observed in RS; no significant differences among treatments were recorded at 20-30 cm depth. Lower MWD and GMD were observed in NT at 30-50 cm depth.

Table 3. The mean weight diameter (MWD) and geometric mean diameter (GMD) at 0-50 cm soil depth under different tillage conditions.

\begin{tabular}{cccc}
\hline Depth $(\mathbf{c m})$ & Treatment & MWD & GMD \\
\hline $0-10$ & RT & $2.88 \pm 0.04 \mathrm{~b}$ & $1.28 \pm 0.06 \mathrm{~b}$ \\
& RS & $2.88 \pm 0.03 \mathrm{~b}$ & $1.23 \pm 0.01 \mathrm{~b}$ \\
NT & $3.20 \pm 0.02 \mathrm{a}$ & $1.66 \pm 0.02 \mathrm{a}$ \\
NS & $3.14 \pm 0.05 \mathrm{a}$ & $1.60 \pm 0.05 \mathrm{a}$ \\
\hline
\end{tabular}


Table 3. Cont.

\begin{tabular}{cccc}
\hline Depth (cm) & Treatment & MWD & GMD \\
\hline $10-20$ & RT & $3.49 \pm 0.11 \mathrm{ab}$ & $1.85 \pm 0.12 \mathrm{~b}$ \\
& RS & $3.71 \pm 0.05 \mathrm{a}$ & $2.20 \pm 0.07 \mathrm{a}$ \\
NT & $3.31 \pm 0.07 \mathrm{~b}$ & $1.74 \pm 0.04 \mathrm{~b}$ \\
& NS & $3.50 \pm 0.04 \mathrm{ab}$ & $1.97 \pm 0.01 \mathrm{ab}$ \\
$20-30$ & RT & $2.95 \pm 0.08 \mathrm{a}$ & $1.29 \pm 0.10 \mathrm{a}$ \\
& RS & $2.99 \pm 0.20 \mathrm{a}$ & $1.20 \pm 0.07 \mathrm{a}$ \\
& NT & $2.71 \pm 0.07 \mathrm{a}$ & $1.10 \pm 0.05 \mathrm{a}$ \\
$30-50$ & NS & $2.89 \pm 0.04 \mathrm{a}$ & $1.23 \pm 0.05 \mathrm{a}$ \\
& RT & $3.84 \pm 0.11 \mathrm{a}$ & $2.36 \pm 0.14 \mathrm{a}$ \\
& RS & $3.69 \pm 0.07 \mathrm{ab}$ & $2.15 \pm 0.06 \mathrm{ab}$ \\
& NT & $3.37 \pm 0.10 \mathrm{~b}$ & $1.84 \pm 0.13 \mathrm{~b}$ \\
& NS & $3.75 \pm 0.15 \mathrm{a}$ & $2.28 \pm 0.18 \mathrm{ab}$ \\
\hline
\end{tabular}

MWD, mean weight diameter; GMD, geometric mean diameter. RT, continuous rotary tillage; RS, rotary tillage + subsoiling; NT, long-term no-till; and NS, no-till + subsoiling. Lowercase letters mean a significant difference at the 0.05 level among treatments.

\subsection{Aggregate Associated Organic Carbon}

At $0-10 \mathrm{~cm}$ depth, higher $\mathrm{AS}_{>2 \mathrm{~cm}}$ and $\mathrm{AS}_{0.25-2 \mathrm{~cm}}$ associated $\mathrm{C}$ was observed in NT and NS compared with RS and RT, and no significant difference was observed in $\mathrm{AS}_{0.053-0.25 \mathrm{~cm}}$ and $\mathrm{AS}_{<0.053 \mathrm{~cm}}$ (Figure 4). At 10-20 cm depth, $\mathrm{AS}_{>2 \mathrm{~cm}}$ associated $\mathrm{C}$ was higher in NS by $25.6 \%, 15.7 \%$, and $28.3 \%$ compared with NT, RS, and RT, respectively. A similar trend was observed in $\mathrm{AS}_{0.25-2 \mathrm{~cm}}$ associated C. At 20-30 cm depth, $A S_{>2 \mathrm{~cm}}$ associated $\mathrm{C}$ was also higher for the NS, whereas no significant difference among treatments was recorded for associated $\mathrm{C}$ at other sizes.

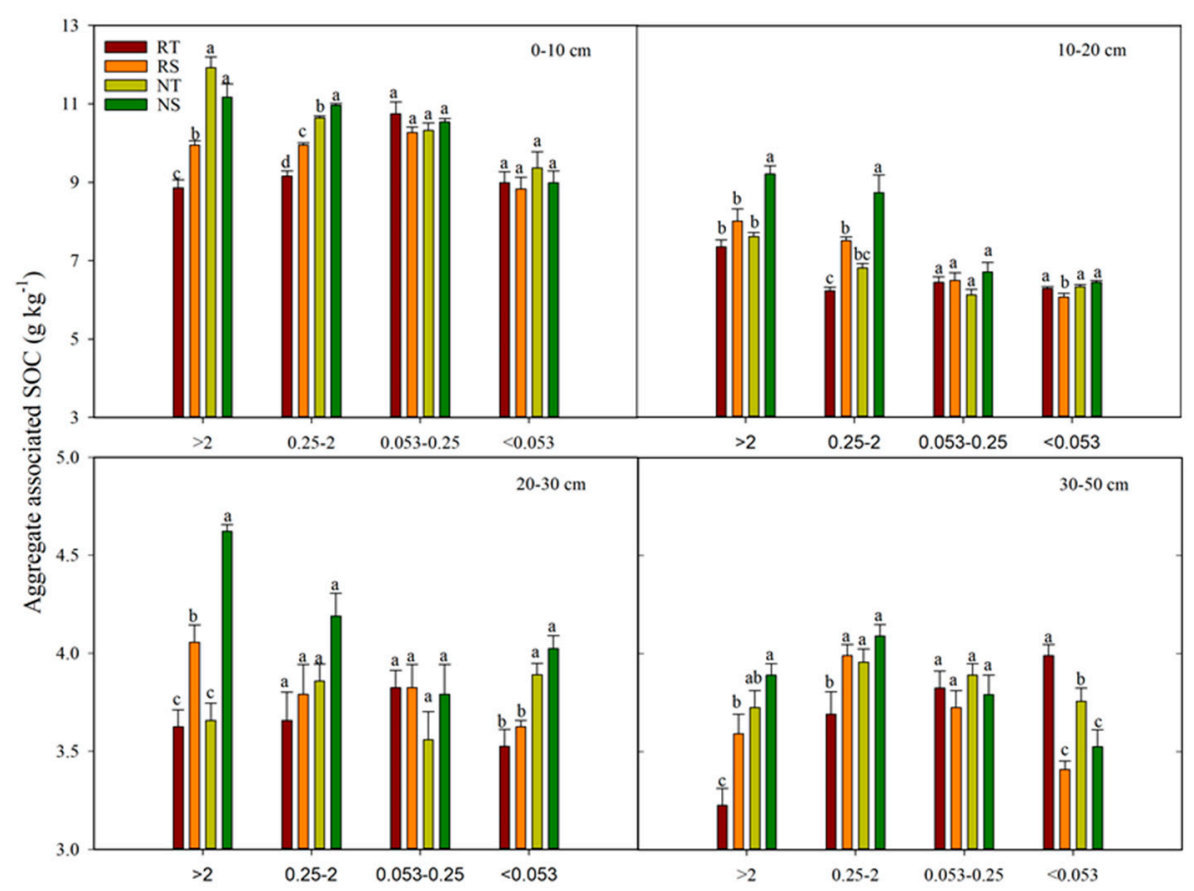

Figure 4. Effects of strategic tillage on aggregate associated soil organic carbon (SOC). RT, continuous rotary tillage; RS, rotary tillage + subsoiling; NT, long-term no-till; and NS, no-till + subsoiling. Lowercase letters mean a significant difference at the 0.05 level among treatments. Error bars represent the standard error of the mean $(n=3)$. 


\subsection{SOC Concentration, Storage, and Stratification Ratio}

Higher SOC concentration was observed in NT and NS at 0-10 cm depth compared with RT and RS ( $p<0.05$; Figure 5). At 10-20 cm depth, SOC concentration in NS was 22.0-28.9\%, 8.7-9.8\%, and 17.0-19.8\% higher than that in RT, RS, and NT, respectively in 2018 and 2019. A similar trend was observed at $20-30 \mathrm{~cm}$ and $30-50 \mathrm{~cm}$ depths, with NS recording the highest values in both years. The NT and NS increased SOC storage at $0-10 \mathrm{~cm}$ depth, significantly higher than that of RT and RS in 2018 ( $p<0.05$; Table 4). At 10-20 cm depth, the highest SOC storage was observed in NS, higher than RT, RS, and NT by $21.6-28.0 \%, 11.8-12.7 \%$, and $9.13-12.3 \%(p<0.05$ in 2019). Additionally, NS significantly increased SOC storage at 20-30 cm depth compared with the other treatments in 2018 $(p<0.05)$. Overall, NS had the highest SOC storage, followed by NT. No significant difference of the stratification ratio was observed among treatments at 0-10:10-20 in 2018 (Table 5). At 0-10:20-30, a significant difference was observed in 2018, with RS and NT higher than RT and NS, whereas no differences were recorded in 2019. At 0-10:30-50, lower SR was observed in NS compared with NT $(p<0.05)$. These results indicated that NT increased SOC concentration and storage at $0-10 \mathrm{~cm}$ depth, whereas NS could increase SOC at deep soil depth, and thus decrease SR of SOC.

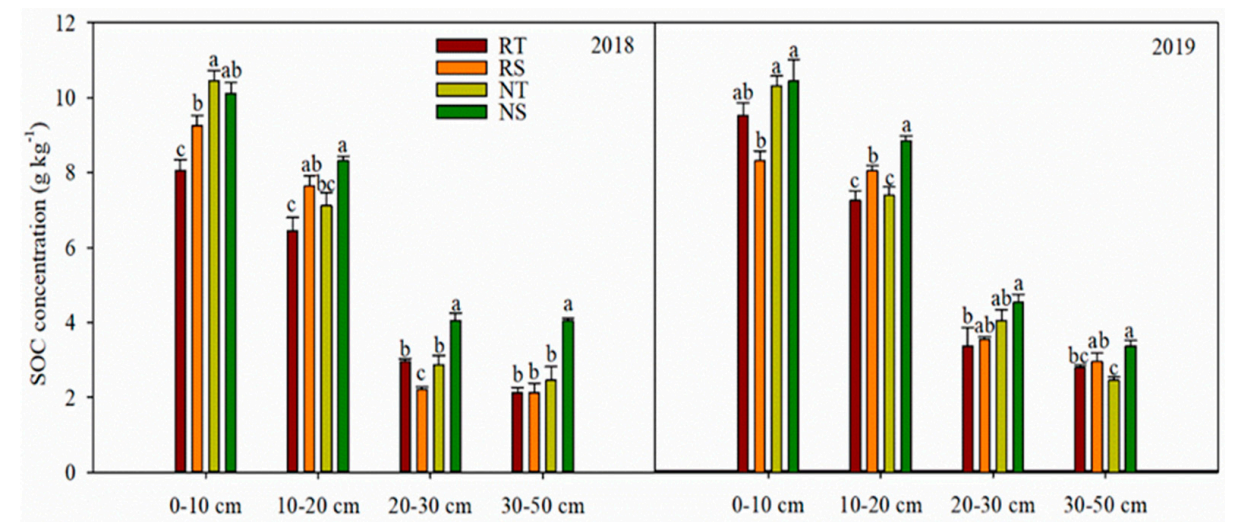

Figure 5. Effects of strategic tillage on soil organic carbon concentration. RT, continuous rotary tillage; RS, rotary tillage + subsoiling; NT, long-term no-till; and NS, no-till + subsoiling. Lowercase letters mean a significant difference at the 0.05 level among treatments. Error bars represent the standard error of the mean $(n=3)$.

Table 4. The SOC storage at 0-30 cm soil depth under different tillage conditions.

\begin{tabular}{cccc}
\hline \multirow{2}{*}{ Depth (cm) } & Treatment & \multicolumn{2}{c}{ SOC Storage (Mg C $\mathbf{~ h}^{-\mathbf{1}} \mathbf{)}$} \\
\cline { 3 - 4 } & & $\mathbf{2 0 1 8}$ & $\mathbf{2 0 1 9}$ \\
\hline $0-10$ & RT & $12.57 \pm 0.37 \mathrm{~b}$ & $14.79 \pm 0.47 \mathrm{a}$ \\
& RS & $13.75 \pm 0.33 \mathrm{~b}$ & $12.63 \pm 0.38 \mathrm{~b}$ \\
& NT & $15.93 \pm 0.44 \mathrm{a}$ & $15.73 \pm 0.41 \mathrm{a}$ \\
& NS & $15.02 \pm 0.35 \mathrm{a}$ & $15.57 \pm 0.75 \mathrm{a}$ \\
\multirow{2}{*}{$10-20$} & RT & $9.52 \pm 0.48 \mathrm{~b}$ & $10.71 \pm 0.34 \mathrm{~b}$ \\
& RS & $10.82 \pm 0.38 \mathrm{ab}$ & $11.65 \pm 0.20 \mathrm{~b}$ \\
& NT & $11.17 \pm 0.55 \mathrm{a}$ & $11.59 \pm 0.36 \mathrm{~b}$ \\
$20-30$ & NS & $12.19 \pm 0.22 \mathrm{a}$ & $13.02 \pm 0.22 \mathrm{a}$ \\
& RT & $4.42 \pm 0.13 \mathrm{~b}$ & $5.06 \pm 0.74 \mathrm{~b}$ \\
& RS & $3.32 \pm 0.12 \mathrm{c}$ & $5.31 \pm 0.13 \mathrm{ab}$ \\
$0-30$ & NT & $4.32 \pm 0.38 \mathrm{~b}$ & $6.08 \pm 0.45 \mathrm{ab}$ \\
& NS & $6.08 \pm 0.32 \mathrm{a}$ & $6.79 \pm 0.32 \mathrm{a}$ \\
& RT & $26.52 \pm 0.35 \mathrm{~d}$ & $30.56 \pm 1.11 \mathrm{~b}$ \\
& RS & $27.88 \pm 0.34 \mathrm{c}$ & $29.59 \pm 0.70 \mathrm{~b}$ \\
& NT & $31.43 \pm 0.22 \mathrm{~b}$ & $33.40 \pm 0.45 \mathrm{a}$ \\
& NS & $33.29 \pm 0.17 \mathrm{a}$ & $35.38 \pm 0.99 \mathrm{a}$ \\
\hline
\end{tabular}

RT, continuous rotary tillage; RS, rotary tillage + subsoiling; NT, long-term no-till; and NS, no-till + subsoiling. Lowercase letters mean a significant difference at the 0.05 level among treatments. 
Table 5. Stratification ratio (SR) of the soil organic carbon under different tillage.

\begin{tabular}{|c|c|c|c|c|c|c|c|c|}
\hline \multirow{2}{*}{$\begin{array}{l}\text { Soil Depth Ratio } \\
\text { (cm:cm) }\end{array}$} & \multicolumn{4}{|c|}{2018} & \multicolumn{4}{|c|}{2019} \\
\hline & RT & RS & NT & NS & RT & RS & NT & NS \\
\hline $0-10: 10-20$ & $1.26 \pm 0.11 \mathrm{a}$ & $1.21 \pm 0.07 \mathrm{a}$ & $1.48 \pm 0.11 \mathrm{a}$ & $1.22 \pm 0.05 \mathrm{a}$ & $1.32 \pm 0.09 \mathrm{a}$ & $1.03 \pm 0.02 b$ & $1.40 \pm 0.08 \mathrm{a}$ & $1.18 \pm 0.07 \mathrm{ab}$ \\
\hline $0-10: 20-30$ & $2.73 \pm 0.04 b$ & $4.22 \pm 0.27 \mathrm{a}$ & $3.69 \pm 0.27 \mathrm{a}$ & $2.53 \pm 0.21 b$ & $2.91 \pm 0.29 \mathrm{a}$ & $2.35 \pm 0.02 \mathrm{a}$ & $2.59 \pm 0.24 \mathrm{a}$ & $2.31 \pm 0.16 a$ \\
\hline $0-10: 30-50$ & $3.81 \pm 0.13 \mathrm{a}$ & $4.47 \pm 0.48 \mathrm{a}$ & $4.43 \pm 0.59 a$ & $2.51 \pm 0.03 b$ & $3.42 \pm 0.08 b$ & $2.84 \pm 0.14 \mathrm{c}$ & $4.21 \pm 0.13 \mathrm{a}$ & $3.12 \pm 0.27 b c$ \\
\hline
\end{tabular}

RT, continuous rotary tillage; RS, rotary tillage + subsoiling; NT, long-term no-till; and NS, no-till + subsoiling. Lowercase letters mean a significant difference at the 0.05 level among treatments. Values represent means \pm standard errors $(n=3)$. 


\subsection{Grain Yield}

Wheat yield in NS (5383.3-5906.7 $\mathrm{kg} \mathrm{ha}^{-1}$ ) was $23.1-24.4 \%, 8.7-13.4 \%$, and $28.4-32.5 \%$ higher than yields in RT, RS, and NT, respectively (Table 6), and significant difference was observed between NS and NT. Maize yield in NS (13931.1-14483.3 $\mathrm{kg} \mathrm{ha}^{-1}$ ) was 14.6-27.2\%, 14.0-25.6\%, and 29.4-29.8\% higher than yields in RT, RS, and NT, respectively $(p<0.05)$. Overall, long-term NT treatment had potential to decrease annual yield (wheat and maize), whereas NS increased yield compared with RT and RS.

Table 6. Grain yield $\left(\mathrm{kg} \mathrm{ha}^{-1}\right)$ under different tillage practices.

\begin{tabular}{ccccccc}
\hline \multicolumn{7}{c}{$\mathbf{2 0 1 8}$} \\
\hline Treatment & Wheat & Maize & Annual & Wheat & Maize & Annual \\
\hline \multirow{2}{*}{ RT } & $4798.33 \pm$ & $12641.67 \pm$ & $17440.00 \pm$ & $4326.67 \pm$ & $10953.89 \pm$ & $15280.56 \pm$ \\
& $169.74 \mathrm{~b}$ & $387.98 \mathrm{~b}$ & $273.89 \mathrm{~b}$ & $265.48 \mathrm{~b}$ & $512.32 \mathrm{~b}$ & $743.48 \mathrm{~b}$ \\
RS & $5208.33 \pm$ & $11534.72 \pm$ & $16743.06 \pm$ & $4951.67 \pm$ & $12221.94 \pm$ & $17173.61 \pm$ \\
& $396.38 \mathrm{ab}$ & $180.06 \mathrm{~b}$ & $338.50 \mathrm{~b}$ & $333.47 \mathrm{ab}$ & $664.90 \mathrm{ab}$ & $853.27 \mathrm{ab}$ \\
NT & $4601.67 \pm$ & $11155.56 \pm$ & $15757.22 \pm$ & $4063.33 \pm$ & $10767.50 \pm$ & $14830.83 \pm$ \\
& $148.81 \mathrm{~b}$ & $766.64 \mathrm{~b}$ & $777.42 \mathrm{~b}$ & $294.07 \mathrm{~b}$ & $537.64 \mathrm{~b}$ & $799.21 \mathrm{~b}$ \\
\multirow{2}{*}{ NS } & $5906.67 \pm$ & $14483.33 \pm$ & $20390.00 \pm$ & $5383.33 \pm$ & $13931.11 \pm$ & $19314.44 \pm$ \\
& $287.89 \mathrm{a}$ & $552.85 \mathrm{a}$ & $763.89 \mathrm{a}$ & $76.88 \mathrm{a}$ & $792.08 \mathrm{a}$ & $715.40 \mathrm{a}$ \\
\hline
\end{tabular}

RT, continuous rotary tillage; RS, rotary tillage + subsoiling; NT, long-term no-till; and NS, no-till + subsoiling. Lowercase letters mean a significant difference at the 0.05 level among treatments. Values represent means \pm standard errors $(n=3)$.

\section{Discussion}

\subsection{Strategic Tillage Effects on Soil Compaction}

Natural environmental conditions and human disturbance can cause soil compaction, which can be detrimental to crop production [28]. Due to a reduction in soil disturbance and accumulation effect of agricultural machinery traffic pressure, higher soil bulk density (BD) and penetration resistance (PR) were recorded at $0-20 \mathrm{~cm}$ depths under long-term no-till treatment compared with the other tillage systems (Figure 1). These results are consistent with the findings of Çelik et al. [14] and Kan et al. [29], where higher BD values were recorded under NT treatments in topsoil depths compared with RT. Our results indicate that NS based on NT could decrease soil BD and PR, and break compaction induced by long-term NT at $0-20 \mathrm{~cm}$ depth. Similar results were observed by Das et al. [30] and Wang et al. [16] because one-time tillage (subsoiling in our study) improved the unfavorable soil conditions induced by long-term NT. On the contrary, Liu et al. [31] argued that strategic tillage has no significant effect on $\mathrm{BD}$ or other physical properties. These conflicting results may be due to differences in soil texture and soil structure [15], with BD changes taking 3-5 years to stabilize [14].

\subsection{Strategic Tillage Effects on Aggregate Stability}

Aggregate stability, a key index of soil sensitivity used to evaluate soil structure and physical shape [32], is closely linked to macroaggregates, being determined by MWD and GMD [33]. Higher aggregate stability values indicated that the soil was less susceptible to erosion, with macroaggregates accounting for a greater proportion of aggregates [34]. Aggregate stability on the soil surface under NT and NS improved in our study compared with RT and RS, indicating that tillage systems can affect aggregate stability due to a reduction of soil disturbance [33,35] and a decline in aggregate disruption [36]. Higher MWD and GMD on the soil surface under NT promotes nutrient cycling and water movement, having a positive contribution to environmental quality [37]. Positive effects of aggregate stability were limited at $0-10 \mathrm{~cm}$ depth, and no difference was observed at deep soil depth. Since RT was undertaken using a rotary tiller with a depth of $-10 \mathrm{~cm}$, which resulted in a decrease in the macroaggregate percentage only on the surface. Although subsoiling disturbed the 
soil up to a depth of $30 \mathrm{~cm}$, no significant difference was observed between NT and NS at all depths, indicating that NS could sustain the advantages of long-term NT in aggregate stability. However, experimental duration of our study was only for 4 years, and a longer study adopting more than one subsoiling was needed to support our results.

\subsection{Strategic Tillage Effects on SOC}

As binders such as SOC and microbial biomass play an important role in the formation and stability of aggregates, original SOC plays an irreplaceable role in the formation of soil aggregates and structure [18]. Soil aggregates can therefore physically protect SOC from a microorganism attack [38]. A strong positive correlation between SOC and macroaggregates therefore exists whilst SOC and microaggregates have a strong negative correlation [39], indicating that SOC concentration in macroaggregates is higher than in microaggregates. As previously mentioned (Section 4.2), macroaggregates on the soil surface were broken into microaggregates in RT and RS treatments due to heavy soil disturbance, resulting in surface SOC concentrations in RT and RS to be lower than those in NT and NS, a finding that is in accordance with Sithole and Magwaza [40]. Although SOC decreased with increasing soil depth, SR of SOC recorded an opposite trend. The SR of SOC under RT treatment was significantly lower than that under NT due to residues covering the soil surface, which contributed to SOC enrichment, similar to the findings of Zhao et al. [7] and Pu et al. [8] in the NCP. However, long-term NT resulted in a poor exchange capacity between deep and surface soil, thereby limiting SOC accumulation at subsoil depth, whereas NS based on long-term NT alleviated this disadvantage. The subsoiling loosens the soil on the surface of NT, where crop residues were brought to deep soil depth and mixed with subsoil under NS [8], and thus SR of NS was lower than that of NT.

\subsection{Strategic Tillage Effects on Grain Yield}

Due to associated reductions in production costs and soil disturbance, NT has been widely adopted [3]. However, results from our study indicate that grain yield under long-term NT treatment is significantly lower than those under other treatments. These findings have been confirmed using meta-analysis in China and around the world [13]. As one of the major grain-producing areas in China, the NCP is crucial for ensuring food security. With adverse effects induced by long-term NT, new tillage strategies have been explored to alleviate this situation [41]. Quincke et al. [42] reported that one-time tillage (NS) destroyed the soil surface and beneficial effects of NT were reduced, evidencing that yield improvement in NS was weak. Results from our study, however, indicate that NS obtained higher grain yield compared with long-term NT, consistent with the findings of Kettler et al. [43]. Here, strategic tillage broke compaction conditions of the soil surface, perfected the physical condition of the soil, and increased SOC concentrations in the subsoil layer, thereby improving soil conditions, resulting in an increase in productivity. Improvements in the subsoil conditions, therefore, alleviated the adverse effects of one-time tillage on the soil surface. Based on our findings, we conclude that NS is a potential method to reduce the adverse effects of long-term NT.

Suitable tillage in intensive wheat-maize production benefits the system by improving soil physicochemical properties, thereby increasing crop production. Faced with several shortcomings caused by single tillage, farmers are utilizing more flexible NS systems $[16,41]$. Soil quality and environmental conditions, as well as the profitability of the production system, must be considered when adopting NS based on long-term NT. Our findings demonstrate that NS could offset negative effects on soil properties due to intensive crop production under long-term NT in the NCP and promote an increase in wheat and maize yields. However, Quincke et al. [42] reported that grain yield was less with one-time tillage as compared with NT. Different results may be attributed to different crops. Experiment of Quincke et al. [42] was conducted under maize-soybean cropping system, while our experiment was under wheat-maize cropping system. Another, Peixoto et al. [44] found that under water stress conditions, ST improved crop yields. As shown in Figure 1, less precipitation was observed in the wheat season, thus higher potential to improve wheat yield. By applying occasional tillage 
(i.e. subsoiling) into NT systems, it is therefore possible to preserve many of the soil quality benefits of NT management, maintain their sustainability, and increase production to improve profitability. We therefore anticipate NS to be a promising strategy to improve long-term NT problems under the wheat-maize cropping system. Our study mainly focused on the effects of tillage on soil physical properties and SOC, but it is known that soil biology played a vital role in SOC decomposition and accumulation. Thus, further study is needed to investigate the changes in soil biology and its relationship with SOC.

\section{Conclusions}

This study assessed the effects of strategic tillage (NS and RS) on soil physicochemical properties and grain yield (wheat and maize) in the NCP. The NT and NS contributed to macroaggregate formation and SOC at $0-10 \mathrm{~cm}$ depth compared with RT and RS, whereas led to higher soil compaction in NT. Our hypothesis was supported that the negative results induced by long-term NT could be alleviated by NS where the BD in NS was lower than NT by $17.4 \%$ at $0-10 \mathrm{~cm}$ and $14.7 \%$ at $10-20 \mathrm{~cm}$ depth. Macroaggregate formation, associated SOC, and SR were all improved in NS without eliminating the positive effects of NT. Grain yields under NS were 29.4-30.2\% higher than those under NT due to the optimization of soil properties. Therefore, NS should be accepted as a suitable alternative management practice to improve the major constraints faced under long-term NT. In-depth study is necessary to investigate the changes in soil biology and its relationship with SOC to reveal the underlying mechanism of aggregate associated SOC.

Author Contributions: Q.L.: Conceptualization, Data curation, Writing-Original draft preparation; Z.K.: Investigation, Writing-Reviewing and Editing; C.H.: Investigation; H.Z.: Project administration, Supervision. All authors have read and agreed to the published version of the manuscript.

Funding: This work was supported by the National Natural Science Foundation of China (31871582).

Acknowledgments: This work is grateful to all the staff of the Wuqiao Experimental Station of China Agricultural University for their help in obtaining the data. Special thanks go to the anonymous reviewers for their constructive comments in improving this manuscript.

Conflicts of Interest: The authors declare no conflict of interest.

\section{References}

1. Batjes, N.H. Total carbon and nitrogen in the soils of the world. Eur. J. Soil Sci. 2014, 65, 10-21. [CrossRef]

2. Lal, R. Soil carbon sequestration impacts on global climate change and food security. Science 2004, 304, 1623-1627. [CrossRef] [PubMed]

3. Zhang, H.L.; Lal, R.; Zhao, X.; Xue, J.F.; Chen, F. Opportunities and challenges of soil carbon sequestration by conservation agriculture in China. Adv. Agron. 2014, 124, 1-36.

4. Busari, M.A.; Kukal, S.S.; Kaur, A.; Bhatt, R.; Dulazi, A.A. Conservation tillage impacts on soil, crop and the environment. Intern. Soil Water Conserv. Res. 2015, 3, 119-129. [CrossRef]

5. Zhao, X.; Zhang, R.; Xue, J.F.; Pu, C.; Zhang, X.Q.; Liu, S.L.; Chen, F.; Lal, R.; Zhang, H.L. Management-induced changes to soil organic carbon in China: A Meta-analysis. Adv. Agron. 2015, 134, 1-50.

6. Prestele, R.; Hirsch, A.L.; Davin, E.L.; Seneviratne, S.I.; Verburg, P.H. A spatially explicit representation of conservation agriculture for application in global change studies. Glob. Chang. Biol. 2018, 24, 4038-4053. [CrossRef]

7. Zhao, X.; Xue, J.F.; Zhang, X.Q.; Kong, F.L.; Chen, F.; Lal, R.; Zhang, H.L. Stratification and Storage of Soil Organic Carbon and Nitrogen as Affected by Tillage Practices in the North China Plain. PLoS ONE 2015, 10, e0128873. [CrossRef]

8. Pu, C.; Kan, Z.R.; Liu, P.; Ma, S.T.; Qi, J.Y.; Zhao, X.; Zhang, H.L. Residue management induced changes in soil organic carbon and total nitrogen under different tillage practices in the North China Plain. J. Integr. Agric. 2019, 18, 1337-1347. [CrossRef] 
9. Xue, J.F.; Pu, C.; Liu, S.L.; Chen, Z.D.; Chen, F.; Xiao, X.P.; Zhang, H.L. Effects of tillage systems on soil organic carbon and total nitrogen in a double paddy cropping system in Southern China. Soil Tillage Res. 2015, 153, 161-168. [CrossRef]

10. Qin, R.; Noulas, C.; Herrera, J.M. Morphology and distribution of wheat and maize roots as affected by tillage systems and soil physical parameters in temperate climates: An overview. Arch. Agron. Soil Sci. 2018, 64, 747-762. [CrossRef]

11. Alesso, C.A.; Masola, M.J.; Carrizo, M.E.; Cipriotti, P.A.; Imhoff, S.D. Spatial variability of short-term effect of tillage on soil penetration resistance. Arch. Agron. Soil Sci. 2019, 65, 822-832. [CrossRef]

12. Pittelkow, C.M.; Liang, X.; Linquist, B.A.; van Groenigen, K.J.; Lee, J.; Lundy, M.E.; van Gestel, N.; Six, J.; Venterea, R.T.; van Kessel, C. Productivity limits and potentials of the principles of conservation agriculture. Nature 2015, 517, 365. [CrossRef] [PubMed]

13. Zhao, X.; Liu, S.L.; Pu, C.; Zhang, X.Q.; Xue, J.F.; Ren, Y.X.; Zhao, X.L.; Chen, F. Crop yields under no-till farming in China: A meta-analysis. Eur. J. Agron. 2017, 84, 67-75. [CrossRef]

14. Çelik, İ.; Günal, H.; Acar, M.; Acir, N.; Bereket, B.Z.; Budak, M. Strategic tillage may sustain the benefits of long-term no-till in a Vertisol under Mediterranean climate. Soil Tillage Res. 2019, 185, 17-28. [CrossRef]

15. Crawford, M.H.; Rincon-Florez, V.; Balzer, A.; Dang, Y.P.; Carvalhais, L.C.; Liu, H.; Schenk, P.M. Changes in the soil quality attributes of continuous no-till farming systems following a strategic tillage. Soil Res. 2015, 53, 263. [CrossRef]

16. Wang, X.; Qi, J.Y.; Liu, B.Y.; Kan, Z.R.; Zhao, X.; Xiao, X.P.; Zhang, H.L. Strategic tillage effects on soil properties and agricultural productivity in the paddies of southern China. Land Degrad. Dev. 2019, 31, 1277-1286. [CrossRef]

17. Dang, Y.P.; Balzer, A.; Crawford, M.; Rincon-Florez, V.; Liu, H.; Melland, A.R.; Antille, D.; Kodur, S.; Bell, M.J.; Whish, J.P.M.; et al. Strategic tillage in conservation agricultural systems of north-eastern Australia: Why, where, when and how? Environ. Sci. Pollut. R. 2018, 25, 1000-1015. [CrossRef]

18. Six, J.; Elliott, E.T.; Paustian, K. Soil macroaggregate turnover and microaggregate formation: A mechanism for C sequestration under no-tillage agriculture. Soil Biol. Biochem. 2000, 32, 2099-2103. [CrossRef]

19. Wortmann, C.S.; Drijber, R.A.; Franti, T.G. One-time tillage of no-till crop land five years post-tillage. Agron. J. 2010, 102, 1302. [CrossRef]

20. Grandy, A.S.; Robertson, G.P. Aggregation and organic matter protection following tillage of a previously uncultivated soil. Soil Sci. Soc. Am. J. 2006, 70, 1398. [CrossRef]

21. Gao, L.Y.; Becker, E.; Liang, G.P.; Houssou, A.A.; Wu, H.J.; Wu, X.P.; Cai, D.X.; Degré, A. Effect of different tillage systems on aggregate structure and inner distribution of organic carbon. Geoderma 2017, 288, 97-104. [CrossRef]

22. Guan, D.H.; Zhang, Y.S.; Al-Kaisi, M.M.; Wang, Q.Y.; Zhang, M.C.; Li, Z.H. Tillage practices effect on root distribution and water use efficiency of winter wheat under rain-fed condition in the North China Plain. Soil Tillage Res. 2015, 146, 286-295. [CrossRef]

23. Kan, Z.R.; Ma, S.T.; Liu, Q.Y.; Liu, B.Y.; Virk, A.L.; Qi, J.Y.; Zhao, X.; Lal, R.; Zhang, H.L. Carbon sequestration and mineralization in soil aggregates under long-term conservation tillage in the North China Plain. Catena 2020, 188, 104428. [CrossRef]

24. Pirmoradian, N.; Sepaskhah, A.R.; Hajabbasi, M.A. Application of fractal theory to quantify soil aggregate stability as influenced by tillage treatments. Biosyst. Eng. 2005, 90, 227-234. [CrossRef]

25. Meng, Q.F.; Sun, Y.T.; Zhao, J.; Zhou, L.R.; Ma, X.F.; Zhou, M.; Gao, W.; Wang, G.C. Distribution of carbon and nitrogen in water-stable aggregates and soil stability under long-term manure application in solonetzic soils of the Songnen plain, northeast China. J. Soil. Sediment. 2014, 14, 1041-1049. [CrossRef]

26. Bao, S.D. Methods for Soil Agricultural and Chemical Analysis; China Agricultural Press: Beijing, China, 2000.

27. Franzluebbers, A.J. Soil organic matter stratification ratio as an indicator of soil quality. Soil Tillage Res. 2002, 66, 95-106. [CrossRef]

28. Batey, T.; McKenzie, D.C. Soil compaction: Identification directly in the field. Soil Use Manag. 2006, 22, 123-131. [CrossRef]

29. Kan, Z.R.; Liu, Q.Y.; He, C.; Jing, Z.H.; Virk, A.L.; Qi, J.Y.; Zhao, X.; Zhang, H.L. Responses of grain yield and water use efficiency of winter wheat to tillage in the North China Plain. Field Crops Res. 2020, 249, 107760. [CrossRef] 
30. Das, A.; Lal, R.; Patel, D.P.; Idapuganti, R.G.; Layek, J.; Ngachan, S.V.; Ghosh, P.K.; Bordoi, J. Effects of tillage and biomass on soil quality and productivity of lowland rice cultivation by small scale farmers in North Eastern India. Soil Tillage Res. 2014, 143, 50-58. [CrossRef]

31. Liu, H.; Crawford, M.; Carvalhais, L.C.; Dang, Y.P.; Dennis, P.G.; Schenk, P.M. Strategic tillage on a Grey Vertosol after fifteen years of no-till management had no short-term impact on soil properties and agronomic productivity. Geoderma 2016, 267, 146-155. [CrossRef]

32. Barthès, B.; Roose, E. Aggregate stability as an indicator of soil susceptibility to runoff and erosion; validation at several levels. Catena 2002, 47, 133-149. [CrossRef]

33. Kan, Z.R.; Virk, A.L.; He, C.; Liu, Q.Y.; Qi, J.Y.; Dang, Y.P.; Zhao, X.; Zhang, H.L. Characteristics of carbon mineralization and accumulation under long-term conservation tillage. Catena 2020, 193, 104636. [CrossRef]

34. Piccolo, A.; Pietramellara, G.; Mbagwu, J.S.C. Use of humic substances as soil conditioners to increase aggregate stability. Geoderma 1997, 75, 267-277. [CrossRef]

35. Alvarez, R.; Steinbach, H.S. A review of the effects of tillage systems on some soil physical properties, water content, nitrate availability and crops yield in the Argentine Pampas. Soil Tillage Res. 2009, 104, 1-15. [CrossRef]

36. Bhattacharyya, P.; Nayak, A.K.; Mohanty, S.; Tripathi, R.; Shahid, M.; Kumar, A.; Raja, R.; Panda, B.B.; Roy, K.S.; Neogi, S.; et al. Greenhouse gas emission in relation to labile soil C, N pools and functional microbial diversity as influenced by 39 years long-term fertilizer management in tropical rice. Soil Tillage Res. 2013, 129, 93-105. [CrossRef]

37. Kibet, L.C.; Blanco-Canqui, H.; Jasa, P. Long-term tillage impacts on soil organic matter components and related properties on a Typic Argiudoll. Soil Tillage Res. 2016, 155, 78-84. [CrossRef]

38. Bronick, C.J.; Lal, R. Soil structure and management: A review. Geoderma 2005, 124, 3-22. [CrossRef]

39. Kushwaha, C.P.; Tripathi, S.K.; Singh, K.P. Soil organic matter and water-stable aggregates under different tillage and residue conditions in a tropical dryland agroecosystem. Appl. Soil Ecol. 2001, 16, 229-241. [CrossRef]

40. Sithole, N.J.; Magwaza, L.S. Long-term changes of soil chemical characteristics and maize yield in no-till conservation agriculture in a semi-arid environment of South Africa. Soil Tillage Res. 2019, 194, 104317. [CrossRef]

41. Kirkegaard, J.A.; Conyers, M.K.; Hunt, J.R.; Kirkby, C.A.; Watt, M.; Rebetzke, G.J. Sense and nonsense in conservation agriculture: Principles, pragmatism and productivity in Australian mixed farming systems. Agric. Ecosyst. Environ. 2014, 187, 133-145. [CrossRef]

42. Quincke, J.A.; Wortmann, C.S.; Mamo, M.; Franti, T.; Drijber, R.A.; Garc1'a, J.P. One-time tillage of no-till systems: Soil physical properties, phosphorus runoff, and crop yield. Am. Soc. Agron. 2007, 99, 1104-1110. [CrossRef]

43. Kettler, T.A.; Lyon, D.J.; Doran, J.W.; Powers, W.L.; Stroup, W.W. Soil quality assessment after weed-control tillage in a no-till wheat-fallow cropping system. Soil Sci. Soc. Am. J. 2000, 64, 339-346. [CrossRef]

44. Peixoto, D.S.; Silva, L.D.C.M.; Melo, L.B.B.D.; Azevedo, R.P.; Araújo, B.C.L.; Carvalho, T.S.D.; Moreira, S.G.; Curi, N.; Silva, B.M. Occasional tillage in no-tillage systems: A global meta-analysis. Sci. Total Environ. 2020, 745, 140887. [CrossRef] [PubMed]

(C) 2020 by the authors. Licensee MDPI, Basel, Switzerland. This article is an open access article distributed under the terms and conditions of the Creative Commons Attribution (CC BY) license (http://creativecommons.org/licenses/by/4.0/). 